\title{
Peranan Sistem Agribisnis terhadap Keberhasilan Tumpangsari Cabai-Tembakau (Kasus Subak Di Desa Sukawati, Kecamatan Sukawati, Kabupaten Gianyar)
}

\author{
SURATA ADNYANA, I MADE NARKA TENAYA ${ }^{1)}$, \\ DWI PUTRA DARMAWAN ${ }^{2}$
}

Program Studi Magister Agribisnis, Program Pascasarjana, Universitas Udayana, E-mail: surataadnyana@yahoo.com

\section{ABSTRACT \\ The Role of System Agribusiness On Intercropping Success Of Chili-Tobacco (Subak Case in Sukawati Village, Sukawati Sub-District, Gianyar District)}

Agricultural development in Indonesia is still the mainstay and the most important sectors of the overall economy. One of the way, developing the potential of regions that still exist through horticulture and folk plantation and implement the correct agribusiness management system. Agribusiness as a sector of the folk economy still have bright prospects for further development, both to reinforce the folk's economy as well as Indonesia state devisa.

Sukawati village very potential to develop the chili-tobacco intercropping system because it has the most suitable land and widest in Gianyar district. Chilitobacco plants have the same genus, can grow well, have local varieties that still exist, tobacco be grown are tobacco of the folk plantations who are used to the fringe.

The study was conducted in the Sukawati Village that be selected purposively. The study population was all the farmers who have applied intercropping farming system of chilli-tobacco in 2013 and 2014 in 13 Subak in the Sukawati Village. The research sample amount 90 respondents were selected by simple random sampling method. The data were analyzed using quantitative descriptive method and relationship analysis with the partial least square (PLS) with help Smart PLS program.

The analysis showed that are: (1) sub-systems procurement and distribution of production facilities contribute positive and significant toward the intercropping success of chilli-tobacco with good category; (2) sub-systems of farming contribute positive and significant toward the intercropping success of chilli-tobacco with good category; (3) sub-system of post-harvest and processing advanced contribute positive and significant toward the intercropping success of chilli-tobacco with good category; (4) sub-system marketing contribute positive and significant to the intercropping success of chilli-tobacco with less good category; and (5) sub-system supporting services contribute positive and significant toward the intercropping success of chillitobacco with good category.

Suggestions can be submitted are: (1) informal education of farmers in the form of field schools and training should be improved; (2) the farmer groups that have 
formed a cooperative to business of production facilities only fertilizers need to cooperate with village government to form village-owned enterprises (BUMDES) in order to able to market the chilli-tobacco so that price stability can be maintained; and (3) other studies with the model and different variables need to be done further.

Key words: role, agribusiness system, intercropping success

\section{Pendahuluan}

Pembangunan pertanian di Indonesia masih menjadi sektor andalan dan terpenting dari keseluruhan pembangunan ekonomi, karena sektor pertanian ini terbukti lebih tangguh didalam menghadapi krisis global jika dibandingkan dengan sektor-sektor lainnnya. Salah satu tolak ukur daripada kemampuan atau daya beli petani yang ada di perdesaan adalah melalui nilai tukar petani (NTP).

Pencapaian target NTP pada sektor pertanian yang belum maksimal disebabkan oleh sistem manajemen agribisnis yang dimulai dari hulu, tengah dan hilir kurang terintegrasi secara terpadu seperti: (1) pengadaan bibit unggul yang bermutu dan berkualitas sulit didapatkan; (2) sumberdaya manusia petani yang masih rendah dalam melaksanakan akses teknologi; (3) penanganan pasca panen dan pemasaran yang masih kurang maksimal; dan (4) dukungan dari lembaga penunjang yang masih kurang.

Kecamatan Sukawati khususnya di Desa Sukawati yang terdiri atas 13 subak dengan luas lahan pertanian 756 ha, memiliki karakteristik pertanian usahatani cabaitembakau yang unik yaitu : (1) tanaman cabai-tembakau memiliki genus yang sama bisa tumbuh bersamaan dengan baik, dan merupakan satu-satunya berada di Propinsi Bali; (2) desa sukawati memiliki potensi yang paling cocok dan terluas di Kabupaten Gianyar dalam mengembangkan usahatani cabai-tembakau; (3) memiliki varietas benih lokal cabai-tembakau yang masih sering digunakan; dan (4) jenis tembakau yang digunakan merupakan tembakau perkebunan rakyat. Dengan sistem usahatani tumpangsari cabai-tembakau petani mengharapkan akan memperoleh peningkatan pendapatan dari usahatani yang dikelolanya; tapi pada kenyataanya keuntungan usahatani yang diperoleh petani belum maksimal hal ini disebabkan oleh petani di Desa Sukawati belum menerapkan sistem agribisnis usahatani tumpangsari cabai-tembakau secara proporsional.

\section{Kajian Pustaka}

\section{Manajemen Agribisnis}

Agribisnis adalah suatu kesatuan kegiatan usaha yang meliputi salah satu atau keseluruhan dari mata rantai produksi, pengolahan hasil dan pemasaran yang ada hubungannya dalam pertanian dalam arti luas; yang dimaksud dengan pertanian dalam arti yang luas adalah kegiatan usaha yang menunjang kegiatan pertanian dan kegiatan usaha yang ditunjang oleh kegiatan pertanian (Soekartawi, 2003). Menurut Suparta (2005) konsep sistem agribisnis yaitu keseluruhan aktivitas bisnis dibidang pertanian yang saling terkait dan saling tergantung satu sama lain, mulai dari : (1) subsistem pengadaan dan penyaluran sarana produksi; (2) subsistem usahatani; (3) subsistem pengolahan dan penyimpanan hasil (agroindustri); (4) subsistem pemasaran; dan (5) subsistem jasa penunjang. 


\section{Subsistem Pengadaan dan Penyaluran Sarana Produksi}

Subsistem pengadaan dan penyaluran sarana produksi juga sering disebut sebagai agribisnis hulu (up-stream agribusiness); diartikan sebagai kegiatan yang menginovasi, memproduksi dan mendistribusikan sarana produksi pertanian, baik industri alat mesin pertanian, pupuk, benih serta obat pengendalian hama dan penyakit (Saragih, 1999). Selanjutnya, menurut Distan Provinsi Bali (2010) bahwa agribisnis hulu mencakup industri yang memproduksi barang modal untuk sektor pertanian seperti; industri benih, sayuran, ternak, ikan, industri agrochemical dan industri mesin pertanian.

\section{Subsistem Usahatani}

Menurut Soekartawi (2003) mendefinisikan usahatani sebagai ilmu yang mempelajari bagaimana seseorang mengalokasikan sumberdaya yang ada secara afektif dan efisien untuk tujuan memperoleh keuntungan yang tinggi pada waktu tertentu. Bagi seorang petani, analisa pendapatan merupakan ukuran keberhasilan dari suatu usahatani yang dikelola dan pendapatan ini digunakan untuk memenuhi kebutuhan sehari-hari dan bahkan dapat dijadikan sebagai modal untuk memperluas usahataninya.

\section{Subsistem Pasca Panen dan Pengolahan Lanjutan}

Subsistem pasca panen dan pengolahan lanjutan dapat berfungsi untuk mengadakan pengolahan lanjut baik tingkat primer, sekunder dan tersier untuk mengurangi susut nilai atau meningkatkan mutu produk agar dapat memenuhi kebutuhan dan selera konsumen, serta berfungsi memperlancar pemasaran hasil melalui perencanaan sistem pemasaran yang baik (Suparta, 2005).

\section{Subsistem Pemasaran}

Pemasaran hasil pertanian merupakan suatu kegiatan yang bertujuan untuk meningkatkan dan mengembangkan kegiatan pemasaran suatu produk, kita harus mempertimbangkan saluran pemasaran yang dapat dipakai untuk menyalurkan produk dari produsen ke konsumen. Menurut Khotler, dkk., (1992) mengemukakan bahwa untuk mencapai pasar sasaran, pemasar menggunakan tiga jenis saluran pemasaran yaitu: (1) saluran komonikasi yaitu menyampaikan dan menerima pesan dari pemberi saran; saluran ini mencakup surat kabar, majalah, radio, televisi, surat, telepon, internet dan papan iklan; (2) saluran distribusi untuk menggelar, menjual atau menyampaikan produk fisik atau jasa kepada pelanggan atau pengguna; dan (3) saluran layanan untuk meelakukan transaksi dengan calon pembeli; saluran ini mencakup gudang, perusahaan transportasi, bank dan perusahaan asuransi yang membantu transaksi.

\section{Subsistem Jasa Penunjang}

Subsistem Jasa Penunjang yang meliputi : (1) penyuluhan; (2) penelitian; (3) informasi agribisnis; (4) pengaturan; (5) kredit modal dan (6) transportasi secara aktif maupun pasif berfungsi untuk menyediakan layanan bagi kebutuhan pelaku sistem agribisnis untuk melancarkan aktifitas perusahaan dan sistem agribisnis (Suparta, 2005). Subsistem jasa penunjang juga merupakan penunjang kegiatan pra panen dan pasca panen yang meliputi: (1) sarana tata niaga; (2) perbankan/perkreditan; (3) penyuluhan agribisnis; (4) kelompok tani; (5) infrastruktur agribisnis; (6) koperasi 
agribisnis; (7) BUMN; (8) swasta; (9) penelitian dan pengembangan; (10) pendidikan dan pelatihan; (11) transportasi dan kebijakan pemerintah (Hermawan, 2008).

\section{Kerangka Berfikir, Konsep, Dan Hipotesis Penelitian}

\section{Kerangka Berfikir}

Kegiatan pertanian merupakan upaya manusia mengelola sumber daya alam yaitu lahan, air, tanaman dan hewan yang dapat dibudidayakan manusia untuk memenuhi kebutuhan hidupnya terhadap pangan dan energi sehingga dapat hidup secara layak menurut peradaban dan nilai-nilai sosial budaya yang berkembang. Manajemen agribisnis yang diterapkan di subak-subak tidak lepas dari subsistem yang ada harus bergerak secara terintegrasi dan bersama-sama sehingga keberhasilan daripada agribisnis tumpangsari akan tercapai baik secara provitas maupun produksinya.

Potensi wilayah Kabupaten Gianyar dengan kesuburan lahan, ketersediaan sumber daya air dan faktor-faktor klimatologis yang sesuai untuk kegiatan pertanian dan didukung oleh aspek sosial budaya masyarakat akan memberikan peluang untuk pengembangan kegiatan pertanian. Keberhasilan dalam penerapan sistem agribisnis di Kecamatan Sukawati khususnya subak-subak yang ada di Desa Sukawati diharapkan mampu mendorong tercapainya keberhasilan manajemen agribisnis pada usahatani tumpangsari tanaman cabai-tembakau.

\section{Kerangka Konsep}

(1) Second order konstruk subsistem pengadaan dan penyaluran produksi (X1) terdiri dari atas tujuh first order konstruk yaitu : (a) ketersediaan benih cabai (X1.1); (b) Ketersediaan benih tembakau (X1.2); (c) ketersediaan pupuk (X1.3); (d) ketersediaan pestisida (X1.4); (e) ketersediaan handtraktor (X1.5); (f) ketersediaan mesin perajang tembakau (X1.6); dan (g) ketersediaan handsprayer (X1.7) (Gambar 3.2).

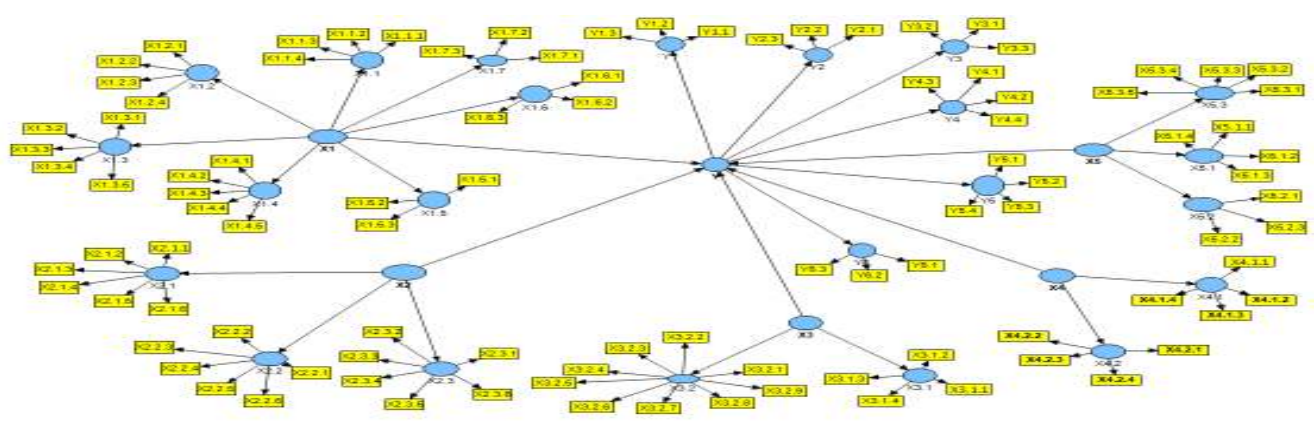

Gambar 3.2

Kerangka Konsep Sistem Agribisnis Tumpangsari

Cabai-Tembakau

(2) Second order konstruk subsistem usahatani ( $\left.\mathrm{X}_{2}\right)$ terdiri dari atas tiga first order konstruk yaitu: (a) usahatani cabai-tembakau (X2.1); (b) usahatani panen dan pasca panen tembakau; dan (c) usahatani cabai (X2.2). (3) Second order konstruk subsistem pasca panen dan pengolahan lanjutan (X3) terdiri dari atas dua first order konstruk yaitu : (a) penanganan pasca panen cabai (X3.1); dan (b) penanganan pasca panen dan pengolahan lanjutan tembakau (X3.2). (4) Second order konstruk subsistem pemasaran hasil (X4) terdiri dari atas dua first order konstruk yaitu : (a) pemasaran cabai (X4.1); dan (b) pemasaran tembakau (X4.2). (5) Second order konstruk subsistem jasa 
penunjang (X5) terdiri dari atas tiga first order konstruk yaitu : (a) Penyuluhan (X5.1); (b) kredit modal (X5.2); dan (c) transportasi (X5.3). (6) Second order konstruk tingkat keberhasilan tumpangsari cabai-tembakau (Y) yang ada di Desa Sukawati terdiri atas enam first order konstruk yaitu: (a) penanaman cabai-tembakau berhasil dan sudah dilakukan berkali-kali (Y1); (b) adanya bantuan subsidi pemerintah berupa saprodi pupuk bertahun-tahun (Y2); (c) secara teknis dapat meningkatkan kesuburan tanah serta menurunkan hama dan penyakit (Y3); (d) berkembangnya ekonomi perdesaan (Y4); (e) terciptanya lapangan kerja (Y5); (f) meningkatnya insentif berusahatani melalui peningkatan produksi (Y6). Kerangka konsep dari penelitian ini dapat dilihat pada Gambar 3.2.

\section{Hipotesis Penelitian}

Hipotesis yang harus diuji kebenarannya dalam penelitian ini adalah:

1. Subsistem pengadaan dan penyaluran produksi berperan positif dan nyata terhadap keberhasilan tumpangsari cabai-tembakau yang ada di Desa Sukawati, Kecamatan Sukawati Kabupaten Gianyar.

2. Subsistem usahatani berperan positif dan nyata terhadap keberhasilan tumpangsari cabai-tembakau yang ada di Desa Sukawati, Kecamatan Sukawati Kabupaten Gianyar.

3. Subsistem pasca panen dan pengolahan lanjutan berperan positif dan nyata terhadap keberhasilan tumpangsari cabai-tembakau yang ada di Desa Sukawati, Kecamatan Sukawati Kabupaten Gianyar.

4. Subsistem pemasaran hasil berperan positif dan nyata terhadap keberhasilan tumpangsari cabai-tembakau yang ada di Desa Sukawati, Kecamatan Sukawati Kabupaten Gianyar.

5. Subsistem jasa penunjang berperan positif dan nyata terhadap keberhasilan tumpangsari cabai-tembakau yang ada di Desa Sukawati, Kecamatan Sukawati Kabupaten Gianyar.

\section{Metode Penelitian}

\section{Lokasi Penelitian}

Penelitian dilakukan di Desa Sukawati, Kecamatan Sukawati, Kabupaten Gianyar, Propinsi Bali. Pemilihan lokasi penelitian secara purposive.

\section{Populasi}

Populasi dalam penelitian ini adalah seluruh petani yang telah menerapkan usahatani tumpangsari cabai-tembakau pada periode tahun 2013 dan 2014 dengan pertimbangan 13 subak dengan luas 387 ha, populasi dalam penelitian ini sebanyak 756 petani di Desa Sukawati, Kecamatan Sukawati, Kabupaten Gianyar.

\section{Sampel penelitian}

Sampel penelitian pada penelitian ini menggunakan metode simple random sampling; penentuan responden menggunakan formulasi teori Slovin (Sevilla, 1993). Dalam penelitian ini diambil sampel sebanyak 90 responden.

\section{Variabel independen}

Pada penelitian ini variabel independen antara lain: 
(1) Second order konstruk subsistem pengadaan dan penyaluran sarana produksi (X1) diukur dengan tujuh first order konstruk yaitu: ketersediaan benih cabai (X1.1); ketersediaan benih tembakau (X1.2); ketersediaan pupuk (X1.3); ketersediaan pestisida (X1.4); ketersediaan handtraktor ( $\left.\mathrm{X}_{1.5}\right)$; ketersediaan mesin perajang tembakau (X1.6); dan ketersediaan handsprayer (X1.7); (2) second order konstruk subsistem usahatani (X2) diukur dengan tiga first order konstruk yaitu: usahatani cabai-tembakau ( $\mathrm{X}_{2.1}$ ); usahatani panen dan pasca panen tembakau (X2.2); dan usahatani cabai (X2.3); (3) second order konstruk subsistem pasca panen dan pengolahan lanjutan (X3) diukur dengan dua first order konstruk yaitu: penanganan pascpanen cabai (X3.1); serta penanganan paasca panen dan pengolahan lanjutan tembakau (X3.2); (4) second order konstruk subsistem pemasaran hasil (X4) diukur dengan dua first order konstruk yaitu: pemasaran cabai (X4.1); dan pemasaran tembakau (X4.2); (5) second order konstruk subsistem jasa penunjang (X5) diukur dengan tiga first order konstruk yaitu: penyuluhan (X5.1); kredit modal (X5.2); dan transportasi (X5.3).

\section{Variabel dependen}

Variabel dependen yang diteliti yaitu second order konstruk keberhasilan agribisnis usahatani tumpangsari cabai-tembakau (Y) terdiri atas tujuh konstruk first order yaitu: (1) penanaman cabai-tembakau berhasil dan sudah dilakukan berkali-kali (Y1); (2) adanya bantuan subsidi pemerintah berupa saprodi pupuk bertahun-tahun (Y2); (3) secara teknis dapat meningkatkan kesuburan tanah serta menurunkan hama dan penyakit (Y3); (4) berkembangnya ekonomi perdesaan (Y4); (5) terciptanya lapangan kerja (Y5); (6) meningkatnya insentif berusaha tani melalui peningkatan produksi (Y6).

\section{Hasil Dan Pembahasan}

\section{Evaluasi model pengukuran (outer model)}

(1) Convergent validity

Skala loading di bawah 0,50 dikeluarkan kemudian model di re-estimasi sehingga semua nilai faktor loading berada diatas atau sama dengan 0,50 .

\section{(2) Discriminant validity}

Semua variabel memiliki nilai $A V E$ berada di atas 0,50 dan nilai $\sqrt{ } A V E$ lebih tinggi daripada korelasi variabel laten

\section{(3) Composite reliability}

Nilai composite reliability menunjukkan bahwa nilai tertinggi ada pada konstruk keberhasilan agribisnis sebesar 0.878 dan nilai terendah pada konstruk subsistem pengadaan dan penyaluran sarana produksi sebesar 0.733 .

\section{Evaluasi model structural ( inner model)}

\section{(1) R-square}

Hasil pengujian menunjukan nilai $R$-square untuk variabel keberhasilan tumpangsari cabai-tembakau sebesar 0,432 relatif moderat (Chin, 1998 dalam Ghozali, 2011). 


\section{(2) Prediction relevance}

Berdasarkan hasil pengujian diperoleh nilai $Q^{2}$ sebesar $0,18 \quad\left(Q^{2}=1-\left(1-R^{2}\right)\right.$ nilai $Q^{2}$ diatas nol memberikan bukti bahwa model memiliki predictive relevance.

\section{Deskripsi Hasil Penelitian \\ Pengadaan dan penyaluran sarana produksi}

Pencapaian skor dari ketersediaan benih cabai tertinggi diperoleh dari indikator ketepatan waktu dalam memdapatkannya yaitu rata-rata 4,03 (80,66\%) yang tergolong tinggi dan terendah pada harga dengan rata-rata nilai 3,16 (63,33\%) yang tergolong sedang; hal ini berarti dalam mendapatkan benih cabai dilapangan petani sangat mudah mendapatkannya.

Ketersediaan benih tembakau menunjukan bahwa nilai rata-rata skor tertinggi diperoleh dalam mendapatkan benih sudah sesuai dengan jumlah kebutuhan yaitu 4,24 $(84,88 \%)$ dan terendah pada harga yaitu dengan nilai 3,68 (73,77\%); namun secara keseluruhan dalam mendapatkan benih tembakau tergolong tinggi dengan rata-rata nilai 3,98 (79,61\%); hal ini berarti dalam mendapatkan benih tembakau sangat mudah untuk didapatkan.

Ketersediaan pupuk seperti menunjukan bahwa nilai rata-rata skor tertinggi diperoleh pada ketersediaan pupuk dalam tepat dosis yaitu $3,74(4,88 \%)$ dan terendah pada harga yaitu dengan nilai $3,05(61,11 \%)$ yang termasuk kategori sedang; namun secara keseluruhan dalam mendapatkan pupuk tergolong tinggi dengan rata-rata nilai 3,58 (71,60\%); hal ini berarti dalam mendapatkan pupuk untuk kebutuhan tanaman tumpangsari cabai-tembakau mudah untuk mendapatkannya

Ketersediaan pestisida menunjukan indikator mutu pestisida yang baik memiliki nilai rata-rata skor tertinggi yaitu $4,02(80,44 \%)$ dan terendah pada harga yaitu dengan nilai 3,92 (78,44\%); namun secara keseluruhan dalam mendapatkan pestisida tergolong tinggi dengan rata-rata nilai 3,95 (79,06\%); hal ini berarti dalam ketersediaan pestisida baik dalam unsur ketepatan waktu, jumlah kebutuhan, jenis kebutuhan, mutu maupun harga yang ada dipasaran mudah untuk didapatkan.

Ketersdiaan handtraktor menunjukan bahwa dalam mengolah tanah unsur tepat waktu mendapatkan skor nilai tertinggi yaitu 3,56 (71,33\%), dimana ketersediaan handtraktor dengan jumlah kebutuhan sudah cukup dari kebutuhan luas lahan yang ada dengan nilai skor 3,38 $(67,77 \%)$. Secara rata-rata ketersediaan akan handtraktor termasuk kategori tinggi dengan nilai 3,94 (69,85\%); artinya dalam mengolah tanah handtraktor mudah untuk didapatkan sesuai dengan kebutuhan.

Ketersediaan akan mesin perajang tembakau, unsur ketepatan waktu dalam menggunakannya mendapatkan skor tertinggi yaitu 3,72 (74,44\%) yang tergolong tinggi, terendah pada kualitas mesinnya yaitu dengan nilai 3,38 (67,77\%) yang tergolong sedang; secara keseluruhan ketersediaan mesin perajang tembakau mendapatkan nilai $3,51(70,22 \%)$ yang tergolong tinggi. Ini berarti dalam hal ketersediaan mesin perajang tembakau mudah untuk didapatkan pada saat menggunakannya

Ketersediaan akan handsprayer unsur ketepatan waktu dalam menggunakannya mendapatkan skor tertinggi yaitu 3,88 (77,77\%) yang tergolong tinggi, terendah pada kualitas barangnya yaitu dengan nilai 3,55 (71,11\%) yang tergolong tinggi; secara keseluruhan ketersediaan handsprayer mendapatkan nilai 3,74 (74,81\%) yang tergolong 
tinggi. Ini berarti dalam hal ketersediaan handsprayer mudah untuk didapatkan pada saat menggunakannya.

\section{Usahatani cabai-tembakau}

Biaya pembibitan dan persemaian cabai-tembakau tertinggi dilakukan oleh delapan $(8,88 \%)$ responden dengan kisaran biaya $>\mathrm{Rp} 107.000 \mathrm{~s} / \mathrm{d} 121.000$ dengan kategori sangat tinggi; sedangkan $17(18,88 \%)$ responden dengan kisaran biaya $50.000 \mathrm{~s} / \mathrm{d}$ 64.000 dengan kategori sangat rendah; secara keseluruhan biaya pembibitan dan persemaian cabai-tembakau memperoleh nilai rata-rata biaya $\mathrm{Rp} 80.600$ termasuk katagori sedang ; hal ini rata-rata petani melakukan pembibitan dan persemaian dilakukan secara sederhana.

Biaya pengolahan tanah cabai-tembakau tertinggi dilakukan oleh empat $(4,44 \%)$ responden dengan kisaran biaya $>\operatorname{Rp} 950.000 \mathrm{~s} / \mathrm{d} 1.170 .000$ dengan kategori sangat tinggi; sedangkan $15(16,66 \%)$ responden dengan kisaran biaya $70.000 \mathrm{~s} / \mathrm{d} 290.000$ dengan kategori sangat rendah; secara keseluruhan biaya pengolahan tanah cabaitembakau memperoleh nilai rata-rata biaya Rp 494.500 termasuk kategori rendah; hal ini berarti petani dalam mengolah tanah sedikit yang melakukan pengolahan tanah secara sempurna.

Biaya penanaman cabai-tembakau tertinggi dilakukan oleh dua $(2,22 \%)$ responden dengan kisaran biaya $>$ Rp 586.000 s/d 700.000 dengan kategori sangat tinggi; sedangkan 25 (27,77\%) responden dengan kisaran biaya Rp 130.000 s/d 244.000 dengan kategori sangat rendah; secara keseluruhan biaya penanaman cabai-tembakau memperoleh nilai rata-rata biaya Rp 314.900 termasuk kategori rendah; artinya petani tumpangsari cabai-tembakau yang ada di Desa Sukawati sudah mampu menekan biaya penanaman cabai-tembakau.

Biaya pemeliharaan cabai-tembakau tertinggi dilakukan oleh satu $(1,11 \%)$ responden dengan kisaran biaya $>$ Rp $3.200 .000 \mathrm{~s} / \mathrm{d} 3.900 .000$ dengan kategori sangat tinggi; sedangkan $88(97,77 \%)$ responden dengan kisaran biaya Rp $400.000 \mathrm{~s} / \mathrm{d}$ 1.100.000 dengan kategori sangat rendah; secara keseluruhan biaya pemeliharaan cabai-tembakau memperoleh nilai rata-rata biaya Rp 730.300 termasuk katagori sangat rendah; artinya biaya pemeliharaan yang terdiri dari biaya pemupukan, biaya penyiangan, biaya pengairan, biaya penyemprotan, dan biaya pemangkasan sudah dapat dikendalikan dan ditekan oleh petani tumpangsari cabai-tembakau.

Biaya pembersihan bekas tanaman tembakau tertinggi dilakukan oleh dua $(2,22 \%)$ responden dengan kisaran biaya $>\mathrm{Rp} 178.000 \mathrm{~s} / \mathrm{d} 210.000$ dengan kategori sangat tinggi; sedangkan 23 (25,55\%) responden dengan kisaran biaya $\mathrm{Rp} 50.000 \mathrm{~s} / \mathrm{d} 82.000$ dengan kategori sangat rendah; secara keseluruhan biaya pembersihan bekas tanaman tembakau memperoleh nilai rata-rata biaya $\mathrm{Rp} 108.800$ termasuk katagori rendah dimana petani telah mampu dalam menekan biaya pembersihan bekas tanaman tembakau.

Biaya tetap usahatani cabai-tembakau tertinggi dilakukan oleh enam $(6,66 \%)$ responden dengan kisaran biaya $>$ Rp $1.200 .000 \mathrm{~s} / \mathrm{d} 1.450 .000$ dengan kategori sangat tinggi; sedangkan 19 (21,11\%) responden dengan kisaran biaya $\mathrm{Rp} 200.000 \mathrm{~s} / \mathrm{d} 450.000$ dengan kategori sangat rendah; secara keseluruhan biaya tetap usahatani cabaitembakau memperoleh nilai rata-rata biaya $\mathrm{Rp} 722.900$ termasuk katagori sedang artinya biaya tetap yang terdiri dari penyusutan alat, iuran subak, bunga pinjaman dan pajak bumi merupakan beban biaya yang memberatkan petani, dimana petani kurang 
mampu dalam menekannya karena berhubungan dengan kebijakan pemerintah maupun organisasi masyarakat tetapi masih tetap pada tahap kewajaran.

\section{Usahatani panen dan pasca panen tembakau}

Pada Tabel 5.20 menunjukan bahwa biaya panen tembakau tertinggi dilakukan oleh enam $(6,66 \%)$ responden dengan kisaran biaya $>$ Rp $773.600 \mathrm{~s} / \mathrm{d} 952.000$ dengan kategori sangat tinggi; sedangkan $23(25,55 \%)$ responden dengan kisaran biaya Rp $60.000 \mathrm{~s} / \mathrm{d} 238.400$ dengan kategori sangat rendah; secara keseluruhan biaya panen tembakau memperoleh nilai rata-rata biaya Rp 359.000 termasuk katagori rendah; artinya biaya panen tembakau telah mampu ditekan serendah-rendahnya oleh petani tumpangsari cabai-tembakau yang ada di Desa Sukawati.

Biaya sebelum tembakau dirajang tertinggi dilakukan oleh empat $(4,44 \%)$ responden dengan kisaran biaya $>\mathrm{Rp} 1.761 .600 \mathrm{~s} / \mathrm{d} 2.142 .000$ dengan kategori sangat tinggi; sedangkan $34(37,77 \%)$ responden dengan kisaran biaya Rp $240.000 \mathrm{~s} / \mathrm{d}$ 620.400 dengan kategori sangat rendah secara keseluruhan biaya sebelum tembakau dirajang memperoleh nilai rata-rata biaya $\mathrm{Rp} 833.000$ termasuk katagori rendah artinya biaya yang terdiri dari pembersihan ibu tulang daun tembakau, pemeraman, dan penggulungan sudah mampu ditekan serendah-rendahnya oleh petani yang ada di Desa Sukawati.

Biaya perajangan dan setelah tembakau dirajang tertinggi dilakukan oleh tiga $(3,33 \%)$ responden dengan kisaran biaya $>$ Rp $2.278 .000 \mathrm{~s} / \mathrm{d} 2.784 .000$ dengan kategori sangat tinggi; sedangkan $10(11,11 \%)$ responden dengan kisaran biaya Rp $254.000 \mathrm{~s} / \mathrm{d}$ 760.000 dengan kategori sangat rendah; secara keseluruhan biaya perajangan dan setelah tembakau dirajang memperoleh nilai rata-rata biaya $\mathrm{Rp} 1.207 .500$ termasuk katagori rendah.

Biaya pupuk tembakau tertinggi dilakukan oleh satu $(1,11 \%)$ responden dengan kisaran biaya $>$ Rp 7.821.600 s/d 9.722.000 dengan kategori sangat tinggi; sedangkan 88 (97,77\%) responden dengan kisaran biaya Rp 220.000 s/d 2.120. 000 dengan kategori sangat rendah; secara keseluruhan biaya pupuk tembakau memperoleh nilai rata-rata biaya $\mathrm{Rp} 822.500$ termasuk katagori sangat rendah artinya biaya pupuk yang dikeluarkan oleh petani untuk memupuk tanaman tembakau kebanyakan hanya menggunakan pupuk urea saja karena fluktuasi harga tembakau yang semakin menurun.

Biaya pestisida tembakau tertinggi dilakukan oleh satu $(1,11 \%)$ responden dengan kisaran biaya $>$ Rp $687.400 \mathrm{~s} / \mathrm{d} 850.000$ dengan kategori sangat tinggi; sedangkan 85 (94,44\%) responden dengan kisaran biaya $\mathrm{Rp} 37.000 \mathrm{~s} / \mathrm{d} 199.600$ dengan kategori sangat rendah; secara keseluruhan biaya pestisida tembakau memperoleh nilai rata-rata biaya $\mathrm{Rp} 110.500$ termasuk katagori sangat rendah karena semakin seringnya kegiatan pemerintah berupa Sekolah Lapang Gerakan Hama Terpadu (SLGHP) dilakukan sehingga dalam membrantas hama penyakit tembakau lebih terarah dan terkendali dengan memanfaatkan musuh alami terlebih dahulu sebelum melakukan pembrantasan secara kimiawi, disamping banyaknya pengecer pestisida yang ada di Desa Sukawati.

Biaya angkut tembakau tertinggi dilakukan oleh satu $(1,11 \%)$ responden dengan kisaran biaya $>$ Rp 330.000 s/d 400.000 dengan kategori sangat tinggi; sedangkan 23 $(25,55 \%)$ responden dengan kisaran biaya $\mathrm{Rp} 50.000 \mathrm{~s} / \mathrm{d} 120.000$ dengan kategori sangat rendah; secara keseluruhan biaya angkut tembakau memperoleh nilai rata-rata biaya Rp 164.000 termasuk katagori rendah artinya petani telah mampu menekan biaya angkut tembakau dengan memakai sarana sepeda motor. 


\section{Usahatani cabai}

Biaya pemeliharaan cabai tertinggi dilakukan oleh satu $(1,11 \%)$ responden dengan kisaran biaya $>$ Rp 5.432.000 s/d 6.700.000 dengan kategori sangat tinggi; sedangkan $89(98,88 \%)$ responden dengan kisaran biaya $\mathrm{Rp} 360.000 \mathrm{~s} / \mathrm{d} 1.628 .000$ dengan kategori sangat rendah; secara keseluruhan biaya pemeliharaan cabai memperoleh nilai rata-rata biaya $\mathrm{Rp} 667.400$ yang termasuk katagori sangat rendah; artinya biaya pemupukan, penyiangan, pengairan, dan penyemprotan tanaman cabai sudah mampu ditekan oleh petani yang ada di Desa Sukawati.

Biaya panen cabai tertinggi dilakukan oleh empat (4,44\%) responden dengan kisaran biaya $>\mathrm{Rp} 13.140 .000 \mathrm{~s} / \mathrm{d} 16.200 .000$ dengan kategori sangat tinggi; sedangkan 27 (30,00\%) responden dengan kisaran biaya Rp 900.000 s/d 3.960.000 dengan kategori sangat rendah; secara keseluruhan biaya panen cabai memperoleh nilai rata-rata biaya $\mathrm{Rp} 6.026 .500$ termasuk katagori rendah.

Biaya benih cabai tertinggi dilakukan oleh satu $(1,11 \%)$ responden dengan kisaran biaya > Rp 164.000 s/d 200.000 dengan kategori sangat tinggi; sedangkan 21 (23,33\%) responden dengan kisaran biaya Rp 20.000 s/d 56.000 dengan kategori sangat rendah; secara keseluruhan biaya pembelian benih cabai memperoleh nilai rata-rata biaya Rp 77.850 termasuk katagori rendah artinya karena menggunakan varietas benih cabai lokal petani yang ada di Desa Sukawati mampu mendapatkan harga yang relative lebih murah dengan kualitas dan mutu yang terbaik.

Biaya pupuk cabai tertinggi dilakukan oleh satu $(1,11 \%)$ responden dengan kisaran biaya $>\mathrm{Rp} 2.269 .000 \mathrm{~s} / \mathrm{d} 2.790 .000$ dengan kategori sangat tinggi; sedangkan 77 $(85,55 \%)$ responden dengan kisaran biaya $\mathrm{Rp} 185.000 \mathrm{~s} / \mathrm{d} 706.000$ dengan kategori sangat rendah; secara keseluruhan biaya pupuk cabai memperoleh nilai rata-rata biaya Rp 568.500 termasuk katagori sangat rendah disebabkan karena saprodi pupuk pengadaannya diserahkan kepada koperasi sehingga harganya relatif lebih murah didapatkan, disamping itu juga karena sering dilakukannya kegiatan Sekolah Lapang Pengelolaan Tanaman Terpadu (SLPTT) aplikasi penggunaan pupuk lebih terarah dan tepat digunakan.

Biaya pestisida cabai tertinggi dilakukan oleh dua (2,22\%) responden dengan kisaran biaya $>\operatorname{Rp} 284.000$ s/d 352.500 dengan kategori sangat tinggi; sedangkan 21 $(23,33 \%)$ responden dengan kisaran biaya $\mathrm{Rp} 10.000 \mathrm{~s} / \mathrm{d} 78.500$ dengan kategori sangat rendah; secara keseluruhan biaya pembelian pestisida cabai memperoleh nilai rata-rata biaya $\mathrm{Rp} 110.500$ termasuk kategori rendah.

Biaya angkut cabai tertinggi dilakukan oleh enam $(6,66 \%)$ responden dengan kisaran biaya $>$ Rp 1.619.000 s/d 2.000.000 dengan kategori sangat tinggi; sedangkan 19 (32,22\%) responden dengan kisaran biaya $\mathrm{Rp} 95.000 \mathrm{~s} / \mathrm{d} 476.000$ dengan kategori sangat rendah; secara keseluruhan biaya angkut cabai memperoleh nilai rata-rata biaya Rp 781.500 termasuk katagori rendah

\section{Pasca panen dan pengolahan lanjutan}

Penanganan pasca panen cabai menunjukan bahwa nilai rata-rata skor tertinggi diperoleh pada pembersihan buah cabai yaitu 3,96 (79,33\%) dengan kategori tinggi dan terendah pada pemilihan buah cabai kedalam kelas mutu dengan nilai 3,93 (78,66\%) yang tergolong tinggi; namun secara keseluruhan dalam penanganan pasca panen cabai memperoleh nilai rata-rata 3,94 (78,94\%) dengan kategori tinggi, dimana petani telah mampu menangani pasca panen cabai dengan baik sehingga tidak terjadi kerusakan. 
Penanganan pasca panen dan pengolahan lanjutan tembakau menunjukan bahwa nilai rata-rata skor tertinggi diperoleh pada pencampuran hasil rajangan daun tembakau yaitu 4,51 (90,22\%) dengan kategori sangat tinggi dan terendah pada pelipatan hasil rajangan tembakau dengan nilai $3,93(78,66 \%)$ yang tergolong tinggi; namun secara keseluruhan dalam penanganan pasca panen dan pengolahan lanjutan tembakau memperoleh nilai rata-rata 4,29 (85,95\%) dengan kategori sangat tinggi; artinya petani yang ada di Desa Sukawati sudah biasa melaksanakan pasca panen cabai-tembakau dengan baik.

\section{Pemasaran hasil}

Pemasaran cabai nilai rata-rata tertinggi diperoleh pada informasi harga cabai yaitu $1,75(43,75 \%)$ termasuk kategori rendah; penentuan harga cabai memiliki nilai terendah yaitu $1,13(28,33 \%)$ yang termasuk kategori rendah; secara umum pemasaran cabai memiliki nilai $1,58(39,71 \%)$ yang termasuk kategori rendah; hal ini disebabkan pemasaran cabai yang dilihat dari aspek wilayah penjualan, tempat penjualan sebagian besar masih dalam sekup antar desa setempat melalui pengumpul dan pelanggan tetap yang sudah ada bertahun-tahun, penentuan harga cabai masih diserahkan kepada pasar dan informasi pasar harga cabai masih kurang intensif didapatkan.

Pemasaran tembakau nilai rata-rata tertinggi diperoleh pada informasi harga tembakau yaitu $1,94(48,61 \%)$ termasuk kategori sedang; penentuan harga tembakau memiliki nilai terendah yaitu $1,45(36,38 \%)$ yang termasuk kategori rendah secara umum pemasaran tembakau memiliki nilai 1,72 (43,19\%) yang termasuk kategori rendah; hal ini disebabkan pemasaran tembakau yang dilihat dari aspek wilayah penjualan, tempat penjualan sebagian besar masih dalam sekup antar desa setempat melalui pengumpul, penentuan harga cabai masih diserahkan kepada pasar dan informasi pasar harga tembakau sudah mulai ada perubahan, dimana petani sudah mulai peka terhadap informasi ini seiring dengan berpluktuasinya harga tembakau, dimana informasi ini didapatkan melalui penyuluh pertanian, ketua kelompok tani yang mengadakan penyuluhan hampir tiap minggu atau bila ada kegiatan penyuluhan pertanian dan perkebunan.

\section{Jasa penunjang}

Penyuluhan nilai rata-rata tertinggi diperoleh pada manfaat kegiatan penyuluhan yaitu 4,08 (81,77\%) termasuk kategori tinggi; lembaga penyuluhan yang paling berhasil memiliki nilai terendah yaitu 3,70 (74,00\%) yang termasuk kategori tinggi; secara umum jasa penunjang berupa penyuluhan mendapatkan nilai rata-rata 3,88 (77,71\%) dengan kategori tinggi; kegiatan penyuluhan yang dilakukan oleh penyuluh pertanian dianggap sangat bermanfaat, aktif, dan penguasaan materi dibandingkan dengan keberadaan penyuluhan swasta lainnya.

Kredit modal memiliki nilai rata-rata tertinggi diperoleh pada sumber kredit untuk melakukan tumpangsari yaitu 3,58 (71,77\%) termasuk kategori tinggi; batas pinjaman kredit memiliki nilai terendah yaitu $2,48(49,77 \%)$ yang termasuk kategori rendah; secara umum kredit modal mendapatkan nilai rata-rata 3,18 (63,84\%) dengan kategori sedang; artinya masalah permodalan untuk melakukan usahatani tumpangsari cabaitembakau mudah untuk didapatkan, disamping peran penyuluh melakukan sosialisasi terhadap akses kredit dari Bank Pemerintah.

Transportasi nilai rata-rata tertinggi diperoleh pada fasilitas transportasi berupa mobil dan motor yaitu 3,61 (72,22\%) termasuk kategori tinggi; kondisi fisik jalan usahatani memiliki nilai terendah yaitu 2,91 (58,22\%) yang termasuk kategori sedang; 
hal ini disebabkan jasa penunjang transportasi yang berupa mobil atau sepeda motor untuk mengangkut sarana produksi, hasil pertanian mudah dujumpai sedangkan kodisi fisik jalan usahatani kurang baik sehingga perlu dilakukan perbaikan-perbaikan; secara keseluruhan subsistem jasa penunjang termasuk kedalam katagori tinggi dengan nilai 3,42 (68,70\%); jasa penyuluhan, kredit modal, transportasi masih mudah didapatkan.

\section{Variabel keberhasilan agribisnis tumpangsari cabai-tembakau}

Penanaman cabai-tembakau berhasil dan sudah dilakukan berkali-kali, unsur penanaman tumpangsari cabai-tembakau sebagai pengganti palawija mendapatkan skor nilai tertinggi yaitu 3,94 (78,88\%) yang termasuk kategori tinggi, terendah pada minat petani untuk merubah tumpangsari cabai-tembakau dengan pola tumpangsari lain yaitu dengan skor nilai 3,91 (78,22\%) yang tergolong tinggi pula; secara keseluruhan keberhasilan penanaman cabai-tembakau berhasil memiliki nilai rata-rata skor 3,92 (78,59\%) yang tergolong tinggi; mengindikasikan penanaman tumpangsari cabaitembakau ini dilakukan dalam rangka mengganti palawija setelah tanaman padi untuk mengatur distribusi air, disamping untuk mengatur pola tanam supaya kesuburan tanah meningkat dan hama penyakit menjadi menurun.

Peran serta pemerintah memberikan subsidi pupuk bertahun tahun ikut memberikan andil keberhasilan agribisnis tumpangsari cabai-tembakau, unsur bantuan pupuk organik mendapatkan skor nilai tertinggi yaitu 4,45 (89,11\%) yang termasuk kategori sangat tinggi, terendah pada bantuan pupuk NPK yaitu dengan skor nilai 3,97 (79,55\%) yang tergolong tinggi; secara keseluruhan adanya bantuan subsidi pemerintah mendapatkan skor nilai 4,20 (84,14\%) yang termasuk kategori tinggi; artinya perhatian pemerintah baik pemerintah pusat maupun daerah dalam hal bantuan pupuk sangat baik terhadap petani yang ada di Desa Sukawati.

Variabel secara teknis dapat meningkatkan kesuburan tanah dan menurunkan hama penyakit terhadap keberhasilan agribisnis tumpangsari cabai-tembakau, indikator kesuburan tanah menjadi lebih meningkat dengan bantuan pupuk dari pemerintah dengan mendapatkan skor nilai tertinggi yaitu 3,98 (79,77\%) yang termasuk kategori tinggi, terendah pada pemanfaatan cabai-tembakau untuk membuat pestisida organik yaitu dengan skor nilai 3,65 (73,11\%) yang tergolong tinggi; secara keseluruhan variabel secara teknis dapat meningkatkan kesuburan tanah serta menurunkan hama penyakit mendapatkan skor nilai $3,82(76,44 \%)$ yang termasuk kategori tinggi; dengan adanya bantuan pupuk dari pemerintah, melakukan tumpangsari cabai-tembakau dan pemanfaatan untuk membuat pestisida organik petani beranggapan akan dapat meningkatkan kesuburan tanah dan menurunkan hama penyakit terutama pada bantuan pupuk organiknya.

Variabel berkembangnya ekonomi perdesaan, indikator terciptanya koperasi tani yang mandiri mendapatkan skor nilai tertinggi yaitu $4,35(87,11 \%)$ yang termasuk kategori sangat tinggi, terendah pada terciptanya unit simpan-pinjam dalam kelompoktani yaitu dengan skor nilai 2,11 (42,22\%) yang tergolong rendah; secara keseluruhan variabel berkembangnya ekonomi perdesaan mendapatkan skor nilai ratarata 3,82 $(73,10 \%)$ yang termasuk kategori tinggi. Terciptanya koperasi yang ada dikelompoktani sebatas hanya melayani aktivitas saprotan berupa pupuk saja dengan tidak melayani unit simpan pinjam; aktivitas berkembangnya usaha masyarakat kecil dan menengah dapat dibuktikan dengan menjamurnya pengusaha-pengusaha lokal desa setempat sebagai pengumpul hasil panen cabai-tembakau. 
Variabel terciptanya lapangan kerja, indikator kelompoktani telah berhasil menciptakan lapangan kerja bagi petani mendapatkan skor nilai rata-rata tertinggi yaitu 4,55 (91,11\%) yang termasuk kategori sangat tinggi, terendah pada kelompoktani telah berhasil menciptakan kelompok pemuda tani yang aktif yaitu dengan skor nilai ratarata $3,73(74,66 \%)$ yang tergolong tinggi; secara keseluruhan variabel terciptanya lapangan kerja mendapatkan skor nilai rata-rata 4,25 (85,16\%) yang termasuk kategori sangat tinggi. Terciptanya lapangan kerja telah dianggap berhasil terhadap tumpangsari cabai-tembakau dengan dibuktikan melalui pemanenan cabai maupun pemrosesaan daun tembakau mulai pemanenan, penghilangan ibu tulang daun, pemeraman, penggulungan, perajangan, penjemuran, pencampuran, pelipatan dan pembungkusan hasil rajangan tembakau, pada tahap ini semuanya menggunakan biaya upah dalam keluarga maupun luar keluarga baik pada pria maupun wanitanya.

Variabel meningkatnya insentif berusahatani melalui peningkatan produksi, indikator kelompoktani telah berhasil meningkatkan produksi usahatani mendapatkan skor nilai rata-rata tertinggi yaitu 4,44 $(88,88 \%)$ yang termasuk kategori sangat tinggi, terendah pada kelompoktani telah berhasil dalam melakukan efisiensi berusahatani yaitu dengan skor nilai rata-rata 3,06 (61,33\%) yang tergolong sedang; secara keseluruhan variabel meningkatnya insentif berusahatani melalui peningkatan produksi mendapatkan skor nilai rata-rata 3,95 $(79,18 \%)$ yang termasuk kategori tinggi.

\section{Peranan Sistem Agribisnis terhadap Keberhasilan Tumpangsari Cabai-Tembakau}

\section{Peranan subsistem pengadaan dan penyaluran produksi terhadap keberhasilan agribisnis tumpangsari cabai-tembakau}

Nilai koefisien parameter jalur yang diperoleh dari peranan subsistem pengadaan dan penyaluran sarana produksi (X1) terhadap keberhasilan tumpangsari cabai-tembakau (Y) sebesar 0,201 dengan nilai t-hitung 4,578 > 1,988 (t-tabel) pada taraf signifikansi 5\%; hal ini menunjukan bahwa hipotesis subsistem pengadaan dan penyaluran sarana produksi berperan positif dan nyata terhadap keberhasilan tumpangsari cabai-tembakau yang ada di Desa Sukawati, Kecamatan Sukawati, Kabupaten Gianyar dapat dibuktikan. Subsistem pengadaan dan penyaluran sarana produksi cabai-tembakau termasuk kategori tinggi dengan nilai rata-rata skor 3,70 (74,19\%) yang artinya ketersediaan benih, ketersediaan pupuk, ketersediaan pestisida, ketersediaan handtraktor, ketersediaan mesin perajang, dan ketersediaan handsprayer dalam melakukan agribisnis usahatani tumpangsari cabai-tembakau di Desa Sukawati mudah didapatkan..

\section{Peranan subsistem usahatani terhadap keberhasilan tumpangsari cabai-tembakau}

Subsistem usahatani berperan positif terhadap keberhasilan tumpangsari cabaitembakau. Nilai koefisien parameter jalur yang diperoleh dari hubungan subsistem usahatani (X2) terhadap keberhasilan tumpangsari cabai-tembakau (Y) sebesar 0,117 dengan nilai t-hitung 2,387 >1,988 (t-tabel) pada taraf signifikansi 5\%; hal ini menunjukan bahwa hipotesis subsistem usahatani berperan positif dan nyata terhadap keberhasilan tumpangsari cabai-tembakau yang ada di Desa Sukawati, Kecamatan Sukawati, Kabupaten Gianyar dapat dibuktikan. Dilihat dari rata-rata skor biaya usahatani petani yang melakukan usahatani agribisnis cabai-tembakau yang ada di Desa Sukawati memiliki nilai rata-rata sangat rendah sampai sedang berarti petani 
tumpangsari cabai-tembakau yang ada di Desa Sukawati sudah mampu menekan biaya yang serendah-rendahnya didalam melakukan usahatani tumpangsari cabai-tembakau.

\section{Peranan subsistem pasca panen dan pengolahan lanjutan terhadap keberhasilan tumpangsari cabai-tembakau}

Subsistem pasca panen dan pengolahan lanjutan berperan positif terhadap keberhasilan tumpangsari cabai-tembakau. Nilai koefisien parameter jalur yang diperoleh dari hubungan subsistem pasca panen dan pengolahan lanjutan (X3) terhadap keberhasilan tumpangsari cabai-tembakau (Y) sebesar 0,241 dengan nilai t-hitung 4,813>1,988 (t-tabel) pada taraf signifikansi 5\%; hal ini menunjukan bahwa hipotesis subsistem pasca panen dan pengolahan lanjutan berperan positif dan nyata terhadap keberhasilan tumpangsari cabai-tembakau yang ada di Desa Sukawati, Kecamatan Sukawati, Kabupaten Gianyar dapat dibuktikan. Subsistem pasca panen dan pengolahan lanjutan cabai-tembakau termasuk kategori tinggi dengan nilai rata-rata skor 4,11 (82,44\%); artinya petani tumpangsari cabai-tembakau yang ada di Desa Sukawati sudah mampu melaksanakan pasca panen dan pengolahan lanjutan cabai-tembakau dengan baik.

\section{Peranan subsistem pemasaran terhadap keberhasilan tumpangsari cabai-tembakau}

Subsistem pemasaran hasil berperan positif terhadap keberhasilan tumpangsari cabaitembakau. Nilai koefisien parameter jalur yang diperoleh dari hubungan subsistem pemasaran hasil (X4) terhadap keberhasilan tumpangsari cabai-tembakau (Y) sebesar 0,153 dengan nilai t-hitung 3,474 >1,988 (t-tabel) pada taraf signifikansi 5\%; hal ini menunjukan bahwa hipotesis subsistem pemasaran berperan positif dan nyata terhadap keberhasilan tumpangsari cabai-tembakau yang ada di Desa Sukawati, Kecamatan Sukawati, Kabupaten Gianyar dapat dibuktikan. Subsistem pemasaran cabai-tembakau termasuk kategori rendah dengan nilai rata-rata skor 1,65 (41,45\%); hal ini disebabkan aspek wilayah penjualan masih kebanyakan antar desa, tempat penjualan kebanyakan di pengumpul, harga masih ditentukan oleh pasar, informasi pasar kurang intensif didapatkan.

\section{Peranan subsistem jasa penunjang terhadap keberhasilan tumpangsari cabai-tembakau}

Subsistem jasa penunjang berperan positif terhadap keberhasilan tumpangsari cabaitembakau. Nilai koefisien parameter jalur yang diperoleh dari hubungan subsistem jasa penunjang (X5) terhadap keberhasilan tumpangsari cabai-tembakau (Y) sebesar 0,437 dengan nilai t-hitung $6,437>1,988$ (t-tabel) pada taraf signifikansi 5\%; hal ini menunjukan bahwa hipotesis subsistem jasa penunjang berperan positif dan nyata terhadap keberhasilan tumpangsari cabai-tembakau yang ada di Desa Sukawati, Kecamatan Sukawati, Kabupaten Gianyar dapat dibuktikan. Subsistem jasa penunjang termasuk kategori tinggi dengan nilai rata-rata skor 3,42 (68,70\%); hal ini berarti subsistem jasa penunjang yang meliputi penyuluhan, kredit modal dan transportasi yang ada di Desa Sukawati sudah berjalan dan terkoordinasi dengan baik.

Berdasarkan peranan konstruk eksogen terhadap konstruk endogen yang ditunjukkan pada pada Gambar 5.1 dapat diketahui seberapa besar peranan langsung antara konstruk eksogen terhadap konstruk endogen. 


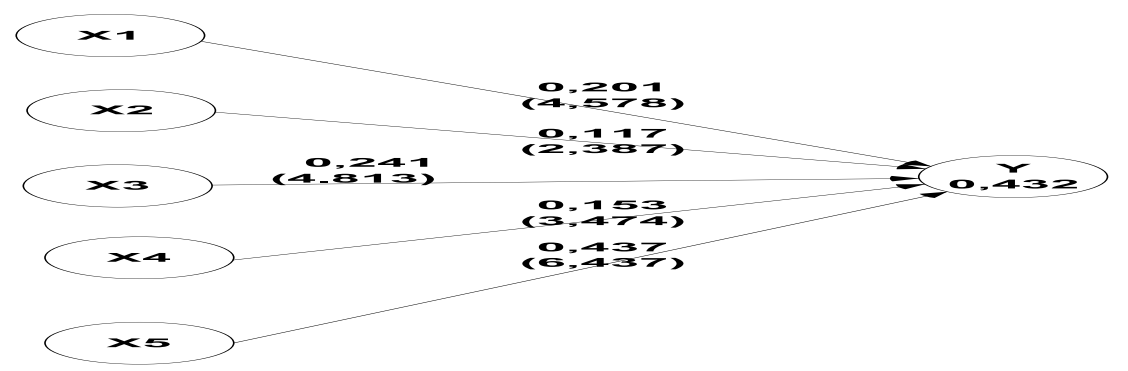

Gambar 5.1

Model Struktural Peranan Konstruk Eksogen Terhadap Konstruk Endogen

Peranan langsung subsistem pengadaan dan penyaluran sarana produksi sebesar 0,201 , peranan langsung subsistem usahatani sebesar 0,117 , peranan langsung subsistem pasca panen dan pengolahan lanjutan sebesar 0,241, peranan langsung subsistem pemasaran hasil sebesar 0,153, peranan langsung jasa penunjang sebesar 0,437 dalam keberhasilan agribisnis tumpangsari cabai-tembakau. Dari kelima faktor tersebut, subsistem jasa penunjang mempunyai peranan langsung yang relatif paling besar $(0,437)$ terhadap keberhasilan tumpangsari cabai-tembakau.

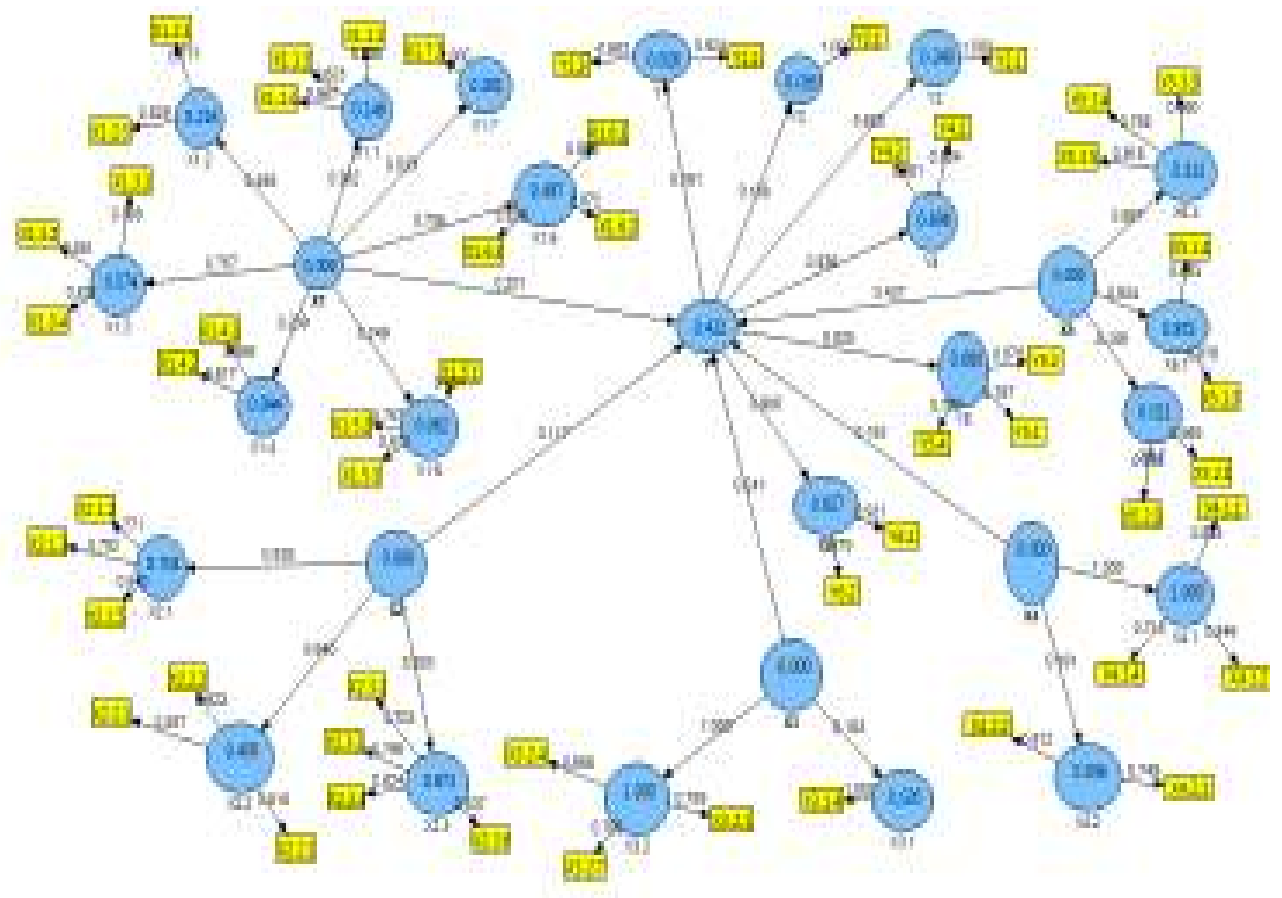

Gambar 5.2

Struktural Penelitian Secara Keseluruhan

\section{Simpulan}

\section{SIMPULAN DAN SARAN}

Berdasarkan hasil analisis dan pembahasan, maka dapat disimpulkan:

1. Subsistem pengadaan dan penyaluran sarana produksi berperan positif dan nyata terhadap keberhasilan tumpangsari cabai-tembakau yang ada di Desa Sukawati, Kecamatan Sukawati, Kabupaten Gianyar. 
2. Subsistem usahatani berperan positif dan nyata terhadap keberhasilan tumpangsari cabai-tembakau yang ada di Desa Sukawati, Kecamatan Sukawati, Kabupaten Gianyar.

3. Subsistem pasca panen dan pengolahan lanjutan berperan positif dan nyata terhadap keberhasilan tumpangsari cabai-tembakau yang ada di Desa Sukawati, Kecamatan Sukawati, Kabupaten Gianyar.

4. Subsistem pemasaran hasil berperan positif dan nyata terhadap keberhasilan tumpangsari cabai-tembakau yang ada di Desa Sukawati, Kecamatan Sukawati, Kabupaten Gianyar.

5. Subsistem jasa penunjang berperan positif dan nyata terhadap keberhasilan tumpangsari cabai-tembakau yang ada di Desa Sukawati, Kecamatan Sukawati, Kabupaten Gianyar.

\section{Saran}

Berdasarkan hasil pembahasan, simpulan dan fakta di lapangan terkait dengan hasil peneltian ini dapat disampaikan beberapa saran, sebagai berikut:

1. Pendidikan informal petani berupa sekolah lapang dan pelatihan yang dibutuhkan perlu lebih ditingkatkan lagi untuk mengimbangi pendidikan formal yang kebanyakan tamatan Sekolah Dasar atau sederajat, sehingga penerapan sistem agribisnis bisa lebih baik.

2. Kelompoktani yang sudah membentuk koperasi, dimana hanya melayani saprodi pupuk saja bisa bekerjasama dengan desa setempat untuk membentuk Badan Usaha Milik Desa (BUMDES) yang dapat memasarkan hasil cabai-tembakau sehingga stabilitas harga dapat dijaga.

3. Penelitian lain dengan model dan variabel-variabel yang berbeda perlu dilakukan sehingga dapat diperoleh nilai $R$-Square yang lebih baik.

\section{Daftar Pustaka}

Dinas Pertanian Tanaman Pangan Propinsi Bali. 2010. Profil Usaha Agribisnis Komoditas Tanaman Pangan don Hortikultura Propinsi Bali. Denpasar

Ghozali, I. 2011. Aplikasi Analisis Multivariate dengan Program IBM SPSS19. Badan Penerbit Universitas Diponegoro. Semarang.

Hermawan, R. 2008. Membangun Sistem Agribisnis. Agroinfo. Yogyakarta.

Kotler, P.and Keller, K.L. 1992. Manajemen Pemasaran. Edisi ke 13. Jilid 2. Penerbit Erlangga. Jakarta.

Saragih, B. 1999. Pembangunan Agribisnis. Pusat Studi Pembangunan. Institut Pertanian Bogor. Bogor.

Sevilla, C.G., Ochave J.A., Punsalan T.G., Regala B.P., dan Uriarte G.G. 1993. Pengantar Metode Penelitian. Alimuddin, Tuwu. (terjemahan). Universitas Indonesia. Jakarta.

Soekartawi. 2003. Analisis Usaha Tani. UI- Press. Jakarta.

Suparta, N. 2005. Pendekatan Holistik Membangun Agribisnis. CV Bali Media Adhikarsa. Denpasar. 